\title{
The Mediating Effect of Operational Performance on the Relationship of Entrepreneurship Toward Financial Performance. A case of Hand Drawn Batik Industry in East Java, Indonesia
}

\author{
Noorlailie Soewarno \\ Faculty of Economics and Business \\ Universitas Airlangga \\ Surabaya, Indonesia \\ noorlailie@gmail.com
}

\author{
Bambang Tjahjadi \\ Faculty of Economics and Business \\ Universitas Airlangga \\ Surabaya, Indonesia \\ bambang.tjahjadi@gmail.com
}

\begin{abstract}
Indonesia has been well known for it's beautiful batik. In fact UNESCO has been awarded batik Indonesia as a masterpiece of oral and intangible heritage of humanity. UNESCO insisted that Indonesia must preserve its heritage. Batik has been part of creative economy in Indonesia. Jawa Timur province had many batik industrial center spreaded in several city, such as Madura, Sidoarjo, Tuban, Tulungagung, etc. Batik, especially hand drawn batik company in Indonesia usually run by entrepreneur of small company. The success of financial performance in hand drawn batik industry was supposedly the result of entrepreneurship of batik company owner / manager, and good operational performance in their internal business process. This study focused on the mediating effect of operational performance on the relationship of entrepreneurship toward financial performance in batik hand drawn industry in East Java Province in Indonesia. This study used quantitative approach. The sample of this study was 111 small business batik company, and analyzed using Warp PLS. Result of the study showed that operational performance mediated the relatioship between entrepreneurship and financial performance. The result of this study contributed input to the policy maker in East Java Province government abot developing sustainable and successful batik industry to boost creative economic activity in East Java Province. This study also gave a contribution in management accounting area especialy about factor that giving impact to financial performance in batik industry.
\end{abstract}

Keywords-entrepreneurship; operational performance; financial performanc; hand drawn batik industry.

\section{INTRODUCTION}

In the era of information, creative industry became more important in economic activity. Creative economy has a potential to be developed because it is based onintellectual resources, information technology and communication [1]. Indonesia has 250 million people, rich in culture, and with the increasing use of technology, Indonesia has the opportunity to increase its economy through creative industry. Indonesia has been predicted by Goldman Sach to become economic superpower country in 2050 . But this prediction will be very difficult to realize if Indonesia still rely on mining, oil and gas, forestry, etc because it means that Indonesia still counting on natural / non renewable resources. On the othe hand, Indonesia should rely on creative industry which is based on creativity, cultural capital, intellectual capital, technology, and communication that could bring multiple value added, so that Indonesia could become economic super power country. According ENESCO, creative industry would be an important sector in the future because its cope a lot of area and value added, increasing job opportunity, increasing revenue growth above industry average, and giving important role in nurturing culture diversity [2].

UNESCO has been ackowledge hand drawn batik Indonesia as intangible heritage of humanity in 2008, after wayang and keris that also has been awarded as intangible heritage of humanity in 2003. The acknowledgement of UNESCO could be a huge benefit for batik industry, as part of creative industry in Indonesia.

Hand drawn batik industry usually are small business company. Entrepreneuship is important aspect in small business company. Entrepreneurship influence performance of a company, wether it is financial or nonfinancial performance [3]. The growing desire of young people to become entrepreneurs, especially in the field of creative industries will drive the growing role of creative industries in improving financial performance, and will eventually be able to contribute to the economic growth of the country. As part of the creative industries, entrepreneurial aspect is very important in the batik industry. Entrepreneurial spirit is believed to penetrate the walls of the barrier that makes the industry stagnant. In the perspective of strategy, entrepreneurship can create value through innovation (value innovation). This view is known as the reconstructionist view of strategy as opposed to the structuralist view of strategy that is rooted in industrial economics [7]. Entrepreneurship has enabled entrepreneurs to innovate outside the black box and creates new markets which deliver high value. Meanwhile, without the innovative 
entrepreneurship, entrepreneurs tend to play on static market filled with competitors. Thus, the value created in the industry contested by several parties that encourage sharp competition.

This research focused on the influence of Entrepreneurship, Operational Performance and Financial Performance in the batik industry in East Java province, with the survey area in the center of large batik industry in East Java, namely in the area of Madura (Tanjung Bumi and Pamekasan), Sidoarjo, Tulungagung, and Tuban.

\section{Literature Review}

The role of entrepreneurship is identified as in [4]: (1) those who dare to take risks in a state of uncertainty; (2) capital providers; (3) those that produce a wide range of innovations; (4) as decision makers; (5) a leader in its business; (6) a manager or superintendent; (7) economic resource managers; (8) the owner of a business or enterprise; (9) the employer; (10) the contractor; (11) a mediator or intermediary; (12) a person who allocates resources to various allocations of interest; and (13) a person who successfully run a new venture in the field of business. The roles of entrepreneurship is important in the success of a business.

Operating Performance is defined as the determinant of outcomes such as quality, productivity, etc., while financial performance is the result achieved for example profitability, etc [12]. Operational performance will have an impact on the success of marketing performance and financial performance [6]. Good internal process business will have a good impact on operating performance. Reference [6] have proposed a new performance management system called the Balanced Scorecard which becomes one of the key findings in management accounting innovations. It provides a tool for executing strategy and aligning daily operational activities of company to strategy. It becomes easier for a company to achieve vision and mission. Ultimate outcomes of value creation is financial performance, especially long-term shareholder value.

Reference [6], operational performance related to:

(1) Establish a relationship with a supplier, for example a low cost of ownership, just in time delivery, highquality supply, new ideas from suppliers, partnering with suppliers.

(2) Producing goods / services such as continuous improvement, process cycle time.

(3) Distribution to customers as responsive delivery time, quality improvement.

(4) Managing risks such as managing operational risk management, and managing technology risk management.

Financial performance is the end result of the work done. Entrepreneurial efforts in improving marketing performance is expected to improve financial performance. Reference [5] states that the financial performance consists of three (3) strategic themes, namely:

\section{(1) Growth and Revenue Mix}

(2) Increase Cost Efficiency

\section{(3) Utilization Asset / Investment}

Performance of revenue growth and revenue mix with is measured with the level of growth in sales and market share for the area, markets, and targeted customers. Business growth is generally triggered by the growth of new products, new applications, customers and new markets, new relationships, new mix, and the new pricing strategy. Performance of increased cost efficiency is measured by increased revenue, cost efficiency, improved distribution channel mix and reduction in operating costs. Performance utilization / investment is measured by optimizing working capital management and asset utilization rate.

With those theory above, hipothesis could be stated as:

H1: Operational performance mediate the influence of entrepreneurship toward financial performance.

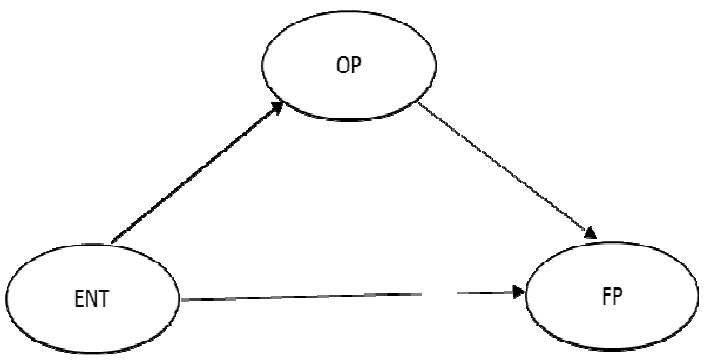

Figure 1. Research Model

Description:

Entrepreneurship (ENT)

Operational Performance (OP)

Financial Performance (FP)

\section{Methodology}

As a quantitative research, this study aims to test empirically the effect of Entrepreneurship, Operational Performance and Financial Performance in the creative industries in East Java batik. Population of this research is all companies in the creative industries in East Java batik in the main centers, namely in Sidoarjo, Madura, Tuban and Tulungagung. Total population of all managers in batik industry are actually difficult to know for sure. This is due to a general phenomenon, namely the high rate of turnover of the companies in the creative industries batik which is mostly small and medium enterprises.

Sample of this research are 111 companies that have been established for at least five (5) years. Quantitative data relating to the variables Entrepreneurship, Operational Performance and Financial Performance obtained through questionnaires.

Entrepreneurship within an organization can be proxied through the character of the entrepreneur as a leader of the organization, and can be seen from: (1) the courage to take risks in a state of uncertainty; (2) capital providers; (3) those that produce a wide range of innovations; (4) as decision 
makers; (5) a leader in its business; (6) a manager or superintendent; (7) economic resource managers; (8) the owner of a business or enterprise; (9) the employer; (10) the contractor; (11) a mediator or intermediary; (12) a person who allocates resources to various allocations of interest; and (13) a person who successfully run a new venture in the field of business. Instruments measuring quantitative data using a Likert scale between 1 and 7.

Operational Performance is the determinant of the final business batik venture, which includes the time of the completion to make batik cloth for variety of quality, efforts to minimize waste, the level of productivity of batik making, quality batik per class, namely batik coarse, medium, or fine, etc. , Quantitative data measurement instrument using a Likert scale ranging between 1 to 7 .

Financial performance is operationalized as the result of efforts in batik company includes sales, profitability, cost efficiency, cash flow, etc. Quantitative data measurement instrument using a Likert scale between 1 and 7.

Data is analyzed using Warp PLS.

\section{RESULT AND DISCUSSION}

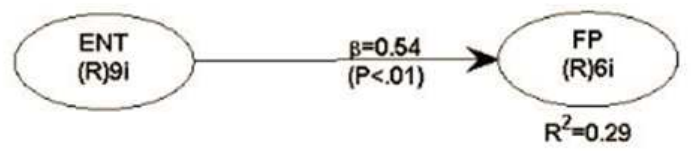

Figure 2. Direct Impact of Entrepreneurship toward Financial Performance

Description:

\section{Entrepreneurship (ENT)}

\section{Financial Performance (FP)}

Entrepreneurship has significant positive influence toward financial performance in batik industry in East Java Province. Statistical result shows that the $\beta$ coefficient is 0.54 . The coefficient of determination $(\mathrm{R} 2)=0,29$, meaning that the $29 \%$ of variability in financial performance in batik industry in East Java is expalained by entrepreneurship of the owner / managers of batik small business company. The $\mathrm{P}$ value is $<0.01$ whis is lower than $\alpha=0.05$. It means that the influence of entrepreurship toward financial performance in batik industry is significant. This result confirm theory dan previus research hat entrepreneurship influence performance of a company, wether it is financial or nonfinancial performance [3]. The financial performance in batik industry depend on entrepreneurship of the managers / owners. Batik company owners / managers create an innovation to increase the batik quality and to appeal its customer. Innovation in batik could be introduce the new design, new motif, new color, etc. Managers in batik industry also cotrol cost so through supervising the employer so that the waste is minimum, controlling the duration of making batik so taht its justified depend on the batik quality, etc. The batik owner/ managers usually also acting as a marketer and spokeperson of the company. That why the entreprenersip skill of the managers / owners of the batik industry directly related to financial performance.

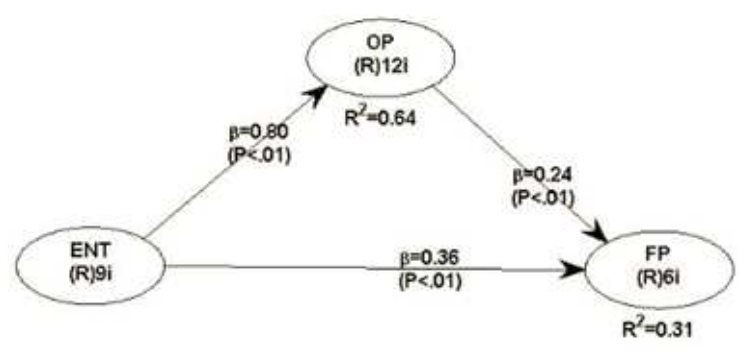

Figure 3. Result Model

Model fit and quality indices

Average path coefficient $(\mathrm{APC})=0.537, \mathrm{P}<0.001$

Average R-squared $(\mathrm{ARS})=0.288, \mathrm{P}<0.001$

Average adjusted R-squared $(\mathrm{AARS})=0.282, \mathrm{P}<0.001$

Average block VIF (AVIF) not available

Average full collinearity VIF (AFVIF) $=1.352$, acceptable if $<=5$, ideally $<=3.3$

Tenenhaus GoF $(\mathrm{GoF})=0.339$, small $>=0.1$, medium $>=0.25$, large $>=0.36$

Sympson's paradox ratio $(\mathrm{SPR})=1.000$, acceptable if $>=0.7$, ideally $=1$

$\mathrm{R}$-squared contribution ratio $(\mathrm{RSCR})=1.000$, acceptable if $>=$ 0.9 , ideally $=1$

Statistical suppression ratio $(\mathrm{SSR})=1.000$, acceptable if $>=0.7$

Nonlinear bivariate causality direction ratio $(\mathrm{NLBCDR})=1.000$, acceptable if $>=0.7$

Indirect effect of entrepreneurship toward financial performance through mediating variable operational performance is confirmed hypothesis in this ressearch because the effect of entrepreneurship to operational performance is significant with $\mathrm{P}<0.01$ value is less than $\alpha=0.05$, the effect of operational performance toward financial performance also significant with with $\mathrm{P}<0.01$ value is less than $\alpha=0.05$. The direct effect of entrepreneurship toward financial performance in the final model is significant with $P<0.01$ value is less than $\alpha=0.05$, and the $\beta$ coefficient is 0.36 , which is lower than in the previus model 0.54 . The decreasing direct effect $\beta$ coefficient in the final model, yet still significant sugessted that the meditaing effect of operational performance on the influence of entrepreneurship toward financial performance is partial. The final model is fit with $(\mathrm{APC})=0.537, \mathrm{P}<0.001$, $(\mathrm{ARS})=0.288, \mathrm{P}<0.001$, and $(\mathrm{AFVIF})=1.352$, acceptable if $<=$ 5 , ideally $<=3.3$. This research confirm Kaplan (2004) 
findings that operational performance influence financial performance, and also that intangibility (entrepreneurship which contain leadership in it) influence operational performance. The more innovation, increasing quality, good leadership, and all of entrepreneurship proxy will lead to increasing operational performance, which in turn will lead to increasing in financial performance.

\section{Conclusion \& Limitation}

Finding of this reasearch is that operational performance mediating the influence of entrepreneurship toward financial performance in batik industry in East Java Province. This study limited because its only cover batik centre in East Java Province. Next research could be done in all batik center in Indonesia.

\section{References}

[1] Anonim, 2013. Menilik Kontribusi Industri Kreatif Bagi Ekonomi Negara. Global Review, 20 Februari 2013, . Diakses dari http://www.majalahglobalreview.com/ekonomi/9perdagangan-/127-menilik-kontribusi-industri-kreatifbagi-ekonomi-negara.html pada tgl 21 Desember 2013 jam 20.13.

[2] Djibran, Fahd, 2013. Kaum Muda, Kelas kreatif, dan Masa Depan Perekonomian Indonesia CoRE. Diakses dari http://www.core.co.id/view/kaum-muda-kelas-kreatifdan-masa-depan-perekonomian-indonesia pada tgl 22 Desember 2013 jam 11.36.

[3] Fox, J.M, 2005. Organizational Entrepreneurship and The Organizational Performance Linkage In University Extension. Dissertation in Ohio University, USA.
[4] Herbert A.F., and A.N. Link, 1989. In Search of The Meaning of Enterpreneurship'. Small Business Economics, Vol I, 39-49.

[5] Kaplan R.S. and D.P. Norton, 2002. The Balanced Scorecard. Boston MA: Harvard Business School Press.

[6] Kaplan R.S. and D.P. Norton, 2004. Strategy Maps: Converting Intangible Assets into Tangible Outcomes. Boston MA: Harvard Business School Press.

[7] Kim, W. Chan. and Renee Mauborgne, 2005. Blue Ocean Strategy: How to Create Uncontested Market Space and Make the Competition Irrelevant, Harvard Business Scool Press

[8] Kirca, A.H., Jayachandran, S., \& Bearden, W.O. 2005. Market Orientation: a meta-analytic review and assesment of its antecedents and impact on performance. Journal of Marketing, 69 (April). 24-41.

[9] Kohli, A.K. \& Jaworski, B. 1990. Market Orientation The Construct, Research Propositions, and Managerial Implications. Journal Of Marketing, 54(April). 1-18.

[10] Narver, J.C. \& Slater, S.F. 1990. The Effect of Market Orientation on Business Provitability. Journal Of Marketing, 54(October). 20-35.

[11] Porter, M.E. 1996. What is Strategy. Harvard Business Review, November-December. Pp 61-78.

[12] Saunila, Minna. 2014. Innovation capability for SMS Success: Perspective of Financial and Operational Performance. Journal of Advances in Management Research, Vol.11, No.2, pp.163-175.

[13] Srivastava, Amit K \& Sushil. 2013. Modeling Strategic Performance Factors for Effective Strategy Execution. International Journal of Productivity and Performance Management, Vol.62, No. 6, pp.554-582. 